4 Affiliations:

$5 \quad{ }^{1}$ Department of Biomedical Engineering, University of California, Irvine.

$6 \quad *$ Correspondence to: jpbrody@uci.edu.

\section{Genetic risk score for ovarian cancer based on chromosomal-scale length variation.}

\author{
Authors: Chris Toh ${ }^{1}$ and James P. Brody ${ }^{1} *$
} can predict whether a woman had been diagnosed with ovarian cancer in this dataset. interval 0.86-0.91). cancer.

\begin{abstract}
:
Introduction. Twin studies indicate that a substantial fraction of ovarian cancers should be predictable from genetic testing. Genetic risk scores can stratify women into different classes of risk. Higher risk women can be treated or screened for ovarian cancer, which should reduce overall death rates due to ovarian cancer. However, current ovarian cancer genetic risk scores, based on SNPs, do not work that well. We developed a genetic risk score based on structural variation, quantified by variations in the length of chromosomes.
\end{abstract}

Methods. We evaluated this genetic risk score using data collected by The Cancer Genome Atlas. From this dataset, we synthesized a dataset of 414 women who had ovarian serous carcinoma and 4225 women who had no form of ovarian cancer. We characterized each woman by 22 numbers, representing the length of each chromosome in their germ line DNA. We used a gradient boosting machine, a machine learning algorithm, to build a classifier that

Results. The genetic risk score based on chromosomal-scale length variation could stratify women such that the highest $20 \%$ had a $160 x$ risk $(95 \%$ confidence interval 50x-450x) compared to the lowest $20 \%$. The genetic risk score we developed had an area under the curve of the receiver operating characteristic curve of 0.88 (estimated $95 \%$ confidence

Conclusion. A genetic risk score based on chromosomal-scale length variation of germ line DNA provides an effective means of predicting whether or not a woman will develop ovarian 
medRxiv preprint doi: https://doi.org/10.1101/2020.07.18.20156976; this version posted July 21, 2020. The copyright holder for this preprint (which was not certified by peer review) is the author/funder, who has granted medRxiv a license to display the preprint in perpetuity.

It is made available under a CC-BY-NC-ND 4.0 International license .

Introduction:

Ovarian cancer kills about 150,000 women per year worldwide[1]. The most common form of ovarian cancer, ovarian serous carcinoma is often diagnosed late (stage III (51\%) or IV $(29 \%)$ ) and has a relatively bleak 5-year survival rate [2]. If women with an elevated risk of developing ovarian cancers could be identified, interventions could be taken that would reduce the number of women who die from ovarian cancer. These interventions include prophylactic oophorectomies, which would completely avoid ovarian cancer, and more targeted screening, which could identify ovarian cancers in earlier stages, where surgery is an effective cure[3-6]. These interventions could both increase 5-year survival times and reduce the overall number of deaths due to ovarian cancer.

A substantial fraction of ovarian cancers should be predictable by genetic testing. The heritability of ovarian cancer has been measured at about $40 \%$ (95\% confidence interval $23 \%$ $55 \%$ ) by the Nordic Twin Study[7]. The maximum discriminative accuracy of a genetic risk test is a function of both the heritability and the prevalence of the disease [8,9]. Based on the measured heritability (about $40 \%$ ) and prevalence (about $0.1 \%$ ) of ovarian cancer, the maximum accuracy, measured by the area under the receiver operating characteristic curve (AUC), should be greater than 0.95 , where 1.0 indicates a perfect test. Current genetic risk scores do not approach that level of accuracy. (SNPs) identified by genome wide association studies[10-15]. These tests, called polygenic risk scores, construct a score based on a linear combination of the value of a collection of SNPs. This 51 strategy has been moderately successful with ovarian cancer. One study followed this strategy to 
medRxiv preprint doi: https://doi.org/10.1101/2020.07.18.20156976; this version posted July 21, 2020. The copyright holder for this preprint (which was not certified by peer review) is the author/funder, who has granted medRxiv a license to display the preprint in perpetuity.

It is made available under a CC-BY-NC-ND 4.0 International license .

52 construct a polygenic risk score where women who scored in the top $20 \%$ had a 3.4 -fold

53 increased risk compared to women who scored in the bottom $20 \%[16]$.

We developed an alternative strategy to compute genetic risk scores. Our strategy is

55 based on structural variation rather than SNPs and uses machine learning algorithms, which

56 include non-linear effects, rather than linear combinations.

\section{Methods:}

58 We tested this strategy with data from the Cancer Genome Atlas (TCGA) project. TCGA

59 was a project sponsored by the National Cancer Institute to characterize the molecular

60 differences in 33 different human cancers[17-19]. The project collected samples from about

6111,000 different patients, all of whom were being treated for one of 33 different types of tumors.

62 The samples collected usually included tissue samples of the tumor, tissue samples of normal

63 tissue adjacent to the tumor and normal blood samples. (Normal blood samples were not

64 available from patients diagnosed with leukemias.)

Most of the patient normal blood samples were processed to extract and characterize germline DNA. All germline DNA samples were processed by a single laboratory, the

67 Biospecimen Core Resource at Nationwide Children's Hospital. Single nucleotide 68 polymorphisms (SNPs) were measured from the patient samples with an Affymetrix SNP 6.0

69 array. This SNP data was then processed (by the TCGA project) through a bioinformatics 70 pipeline [20], which included the packages Birdsuite [21] and DNAcopy [22]. The result of this

71 pipeline is, for each sample, a listing of a chromosomal region (characterized by the chromosome 72 number, a starting location, and an ending location) and the associated value given as the 73 "segmented mean value." The segmented mean value is defined as the logarithm, base 2 of one- 
medRxiv preprint doi: https://doi.org/10.1101/2020.07.18.20156976; this version posted July 21, 2020. The copyright holder for this preprint (which was not certified by peer review) is the author/funder, who has granted medRxiv a license to display the preprint in perpetuity.

It is made available under a CC-BY-NC-ND 4.0 International license .

74 half the copy number. A normal diploid region with two copies will have a segmented mean

75 value of zero.

NCI has provided most of the TCGA data on the Genomic Data Commons [23]. The

77 copy number variation is called the masked copy number variation on the Genomic Data

78 Commons. The masking process removes "Y chromosome and probe sets that were previously

79 indicated to have frequent germline copy-number variation." [20].

This research uses de-identified coded datasets produced by TCGA. Therefore it is not considered human subjects research.

We accessed the TCGA data through Google's BigQuery, a cloud-based database. This resource is hosted and maintained by the Institute of Systems Biology [24]. We used the copy number segment (masked) table extracted from the Genomic Data Commons in February 2017. We also used information from the Biospecimen (extracted April 2017) and Clinical (extracted June 2018) tables. The copy number table contained all the information for the chromosome

87 scale length variation data. The Biospecimen table was used to identify which samples were from normal blood (representing germ line DNA). The Clinical table provided information on the individual patient's gender, race, and ovarian cancer status. Information in the different tables was tied together by the sample barcode parameter.

We used the statistical computer language R to query the BigQuery database, collect the

92 data and manipulate it into different forms. We took extensive care to avoid typical problems

93 that lead to falsely high AUCs in machine learning. For instance, we ensured that no data leakage

94 occurred, which can lead deceivingly high AUCs when copies of a sample appear in both the 95 training and test sets. 
medRxiv preprint doi: https://doi.org/10.1101/2020.07.18.20156976; this version posted July 21, 2020. The copyright holder for this preprint (which was not certified by peer review) is the author/funder, who has granted medRxiv a license to display the preprint in perpetuity.

It is made available under a CC-BY-NC-ND 4.0 International license .

We used the $\mathrm{H} 2 \mathrm{O}$ machine learning package in $\mathrm{R}$ to create machine learning models.

$97 \mathrm{H} 2 \mathrm{O}$ takes care of setting many of the proper default values, depending on whether the goal of the model is classification or regression. For the gradient boosting machine (GBM) models,

$99 \mathrm{H} 2 \mathrm{O}$ performs preprocessing, randomization, encoding categorical variables, and other data processing steps appropriate for the chosen model.

$\mathrm{H} 2 \mathrm{O}$ has an automated machine learning algorithm, named AutoML[25]. Given a spreadsheet like- dataset, AutoML will run through four different machine learning algorithms and evaluate which provides the best models for the given problem. For each of the machine learning algorithms, it will evaluate several different hyperparameters. The process is limited by the amount of time devoted to it. After the allotted time, AutoML reports a scoreboard ranking the best algorithms. For the gradient boosting machine algorithm, we started with the default $\mathrm{H} 2 \mathrm{O}$ settings. These default settings build trees to a maximum depth of five trees with a sample rate of 1 [26]. For the results reported in Table 2, we used an allotted time of one hour. In tests, we found that the results do not change substantially with times up to 10 hours.

We used 5-fold cross validation with the GBM algorithm to produce Table 3 and Figure

2. Cross validation uses repeated model runs with non-overlapping data. This approach allows one to use of all samples in the limited dataset. For Table 3 and Figure 2, we estimated 95\% confidence intervals for the odds ratios following the method described in [27].

Figure 3 was produced with a single model run by splitting the dataset into a training set containing $80 \%$ of the data and a test set containing $20 \%$ of the data.

\section{Results:}

Using the TCGA dataset, we identified a measure that we call chromosome-scale length 
medRxiv preprint doi: https://doi.org/10.1101/2020.07.18.20156976; this version posted July 21, 2020. The copyright holder for this preprint (which was not certified by peer review) is the author/funder, who has granted medRxiv a license to display the preprint in perpetuity.

It is made available under a CC-BY-NC-ND 4.0 International license .

number variations slightly alter the overall length of an individual's chromosome. Thus, the lengths of the set of chromosomes can be used to characterize a person. A histogram showing the distribution of relative chromosome lengths taken from germ line DNA samples in the TCGA dataset is shown in Figure 1. By convention, these lengths are reported in units of log base 2. A value of " 0 " represents the consensus, average, chromosome length.

Figure 1. This figure shows a histogram of chromosome scale length variation for most of chromosomes 1,6,13, and 17. For most patients in the TCGA dataset, a normal blood sample was taken, genomic DNA was extracted from that sample and analyzed with an Affymetrix SNP 6.0 array. The data from this array was processed by the TCGA project through a bioinformatic pipeline that resulted in a segment mean value, which is a number equal to the log base two of one half the copy number value. This histogram indicates that most people have a nominal value of 0 , indicating exactly two copies of the diploid chromosome. A value of 0.02 would indicate the person has on average 2.028 copies of the chromosome, or about $1.4 \%$ longer than the average length of the chromosome.

chromosome-scale length variation data can construct a genetic risk score. We identified 4225

women who had not been diagnosed with any form of ovarian cancer and 414 women who had been diagnosed with ovarian serous carcinoma. Statistical descriptions of the two populations are shown in Table 1.

Table 1. From the TCGA dataset, we constructed two groups, both solely composed of women. The first group, containing 414 women, all had been diagnosed with ovarian serous carcinoma. None of the second group, with 4225 women, had been diagnosed with any form of ovarian cancer. This table compares the two populations.

\section{Diagnosed with Ovarian $\quad$ Not diagnosed with Ovarian \\ Diagnosed with Ovarian $\quad$ Not diagnosed with Ovarian}


medRxiv preprint doi: https://doi.org/10.1101/2020.07.18.20156976; this version posted July 21, 2020. The copyright holder for this preprint (which was not certified by peer review) is the author/funder, who has granted medRxiv a license to display the preprint in perpetuity. It is made available under a CC-BY-NC-ND 4.0 International license .

150

161

Serous Carcinoma

cancer

\begin{tabular}{l|ll} 
Total & 414 & 4225 \\
Mean age & 58.3 years & 59.7 years \\
\% Black & $25 / 414=6 \%$ & $492 / 4225=12 \%$ \\
\% White & $352 / 414=85 \%$ & $3064 / 4225=73 \%$ \\
\% Asian & $14 / 414=3 \%$ & $259 / 42256 \%$
\end{tabular}

Next, we evaluated the effectiveness of several different machine learning algorithms. We measured how well these algorithms could classify a woman, based solely on the set of 23 chromosome-scale length variation measurements, into either the class with ovarian cancer or without. The measurement of success we used was the area under the curve (AUC) of the receiver operating characteristic curve. The results of these measurements are shown in Table 2.

Table 2. This table lists five different machine learning algorithms we evaluated for predicting ovarian cancer from chromosomescale length variation data using the $\mathrm{H} 2 \mathrm{O}$ package in $\mathrm{R}$. The algorithms are ranked by the best AUC it achieved using 5-fold cross validation.

\begin{tabular}{ll}
\hline Algorithm & AUC \\
\hline Gradient Boosting Machine & 0.88 \\
Distributed Random Forest & 0.87 \\
Extremely Randomized Trees & 0.86 \\
Deep learning & 0.82 \\
Generalized Linear Model & 0.68 \\
\hline
\end{tabular}

Based on the results in Table 2, we used the Gradient Boosting Machine algorithm throughout the rest of this manuscript. In the next step, we sought to classify the 4669 women in the dataset. We used a $k$-fold cross validation procedure, with $k=5$. The dataset was randomly partitioned into five equal groups. The first group was held out (to be the test set), while the other four groups were used to train a model to distinguish the two classes (women with ovarian cancer and women without ovarian cancer). The trained model assigned a numerical score to 
medRxiv preprint doi: https://doi.org/10.1101/2020.07.18.20156976; this version posted July 21, 2020. The copyright holder for this preprint (which was not certified by peer review) is the author/funder, who has granted medRxiv a license to display the preprint in perpetuity.

It is made available under a CC-BY-NC-ND 4.0 International license .

each of the women in the first group (test set) quantifying how likely that woman was a member of the ovarian cancer class. The process was repeated 5 times, with a different group held out each time. The result is a numerical score for each of the 4669 women.

The predictions were compared to the known ovarian cancer status of each of the 4669 women. First, all 4669 women were ranked by their score, representing the likelihood that they were from the ovarian cancer class. By comparing this ranking with their known ovarian cancer status, we can evaluate how well the model classified the women.

The comparison is presented in two different forms. Table 3 provides a tabular form of relative risk for the population segmented into five different groups. Figure 2 shows similar information in graphical form, where the population is segmented into 50 groups.

Finally, we took the dataset of 4669 women and split it into a training set $(80 \%)$ and a test set (20\%). Using H2O, we trained a Gradient Boosting Machine model to predict whether a woman was in the group with ovarian cancer, or not. The results are presented in Figure 3, which shows a classic receiver operating characteristic curve of the model's predictions.

Table 3. Using 5-fold cross validation, each woman in the dataset received a score from the model built to predict ovarian cancer. The women were ranked by score from lowest to highest and then partitioned into five quintiles. This table presents the number of women with and without ovarian cancer in each quintile along with the odds ratio (relative to the entire group) and the $95 \%$ confidence interval for the odds ratio. 
medRxiv preprint doi: https://doi.org/10.1101/2020.07.18.20156976; this version posted July 21, 2020. The copyright holder for this preprint (which was not certified by peer review) is the author/funder, who has granted medRxiv a license to display the preprint in perpetuity.

It is made available under a CC-BY-NC-ND 4.0 International license .

190

191

192

193

194

195

196

197

198

199

200

201

202

203

204

205

206

207 208

\begin{tabular}{cccccc} 
Quintile & $\begin{array}{c}\text { Number of } \\
\text { women without } \\
\text { ovarian cancer }\end{array}$ & $\begin{array}{c}\text { Number of } \\
\text { women with } \\
\text { ovarian cancer }\end{array}$ & $\begin{array}{c}\text { Total } \\
\text { number of } \\
\text { women }\end{array}$ & Odds ratio & $\begin{array}{c}\text { 95\% confidence } \\
\text { interval }\end{array}$ \\
\hline $\mathbf{1}$ & 925 & 3 & 928 & 0.03 & $0.01--0.09$ \\
$\mathbf{2}$ & 925 & 3 & 928 & 0.03 & $0.01--0.09$ \\
$\mathbf{3}$ & 901 & 27 & 928 & 0.30 & $0.21--0.45$ \\
$\mathbf{4}$ & 842 & 86 & 928 & 1.04 & $0.82--1.33$ \\
$\mathbf{5}$ & 632 & 295 & 927 & 4.76 & $4.01--5.65$
\end{tabular}

Figure 2. This figure shows that women ranked higher by the predictive model are significantly more likely to have ovarian cancer. The predictive model ranked all 4669 women in the dataset based on their likelihood of having ovarian cancer, based solely on germ line DNA data. This ranking was then split into 50 equal partitions, each with about 93 women. This plot shows the odds ratio (relative to 414 ovarian cases out of 4669 total) of each of the 50 equal partitions along with the $95 \%$ confidence intervals.

\section{Discussion:}

Figure 3. This figure presents a receiver operating characteristic curve of the model's predictions. The area under the curve for this model was 0.88 .

The results presented here compare favorably to other genetic risk scores for ovarian cancer. For instance, a previous study found that a polygenic risk score in the top $20 \%$ conferred a 3.4-fold risk increase compared to women in the bottom 20\% [16]. As seen in Table 3, the top $20 \%$ in our results had an increase of over 100 -fold risk over women who scored in the bottom $20 \%$.

Table 2 quantifies different algorithms applied to this problem. These results are illustrative, but not conclusive. Tuning machine learning models is an art, and it might be possible, for instance, to tune a deep learning network to obtain superior results. In similar work on TCGA colon cancer data, we found that a pairwise neuron network algorithm performs equal to a gradient boosting machine[28]. The gradient boosting machine generally runs faster and is 
medRxiv preprint doi: https://doi.org/10.1101/2020.07.18.20156976; this version posted July 21, 2020. The copyright holder for this preprint (which was not certified by peer review) is the author/funder, who has granted medRxiv a license to display the preprint in perpetuity.

It is made available under a CC-BY-NC-ND 4.0 International license .

214 easier to tune. Others have evaluated different machine learning algorithms for different

215 bioinformatic problems and found that no one algorithm is superior[29]. They also found that a

216 gradient boosting machine algorithm does perform well on many different types of datasets,

217 consistent with out findings.

A disadvantage of this approach, compared to more conventional SNP-based genetic risk scores, is that the results are difficult to understand and extract biological meaning. The Gradient Boosting Machine computational model is complex, consisting of dozens of decisions trees. Furthermore, the data that is used to traverse the decision tree is also complex. The data

222 consists of chromosome scale length variation, which is the result of many different insertions, 223 deletions, translocations, and other structural changes. Polygenic risk scores based on SNPs are 224 easy to interpret. One can identify how much each SNP contributes to the score and one can locate this SNP in the genome and understand the function of nearby genes that might change. Although this approach is lacking in explanatory power, its ultimate goal is predictive power. studies: batch effects or population stratification. We found it unlikely that our model is identifying batch effects rather than real effects. First, all samples were collected from the same tissue, blood. This eliminates one common source of batch effects, since the DNA extraction process is the same for each sample. Second, all samples were processed by the same laboratory, 232 the Nationwide Children's Hospital Biospecimen Core Resource, with the same type of 233 instrument. This laboratory followed the same protocol throughout their processing phase. 234 Finally, we looked up the batch history of each sample. The 424 ovarian cancer samples were 235 processed in 15 separate batches. The non-ovarian samples were processed in several hundred 236 different batches. For these reasons, we do not believe the results are due to batch effects. 
medRxiv preprint doi: https://doi.org/10.1101/2020.07.18.20156976; this version posted July 21, 2020. The copyright holder for this preprint (which was not certified by peer review) is the author/funder, who has granted medRxiv a license to display the preprint in perpetuity.

It is made available under a CC-BY-NC-ND 4.0 International license .

Population stratification occurs in case/control studies when the cases and controls contain substantially different proportions of genetically discernable subclasses. Most TCGA samples were collected in the United States from a racially diverse group. For instance, over half the ovarian cancer samples were collected at five locations in the United States: Memorial Sloan

241 Kettering, Washington University, University of Pittsburgh, Duke, and Mayo Clinic- Rochester.

242 Table 1 lists demographic information about the two populations. Although the table does 243 indicate slightly different proportions, by race, in the case and control groups, it does not seem to 244 be different enough to account for the AUC observed.

This study has several weaknesses. First, the control population in this analysis is not

247 the study because they were diagnosed with another form of cancer. Second, the results rely on a

248 single dataset. The general applicability of this method would be better established if we were 249 able to show that a model trained on one dataset would perform well on a second dataset that was 250 collected independently. Demonstrating that a model is transferrable is a longer-term goal of 251 ours.

Future work could refine this method to improve the predictive ability of this method.

253 The AUC might be improved through several strategies, including feature engineering, for 254 instance using sub-chromosomes rather than complete chromosomes, data augmentation 255 strategies, and the inclusion of SNP data. Further work can also establish how robust the model 256 is: can a model trained with the TCGA data be successfully applied to a person not in the TCGA 257 dataset.

\section{Conclusion:}


A genetic risk score based on chromosomal-scale length variation of germ line DNA

260 provides an effective means of predicting whether or not a woman will develop ovarian cancer.

261 Several avenues are open to further improve the AUC of this genetic risk score test.

\section{Competing Interests:}

$263 \quad$ None of the authors have any competing interests.

\section{Acknowledgements:}

265 The results published here are in whole or part based upon data generated by the TCGA

266 Research Network: http://cancergenome.nih.gov/. 
medRxiv preprint doi: https://doi.org/10.1101/2020.07.18.20156976; this version posted July 21, 2020. The copyright holder for this preprint (which was not certified by peer review) is the author/funder, who has granted medRxiv a license to display the preprint in perpetuity.

\section{References:}

1. Bray F, Ferlay J, Soerjomataram I, Siegel RL, Torre LA, Jemal A. Global cancer statistics 2018: GLOBOCAN estimates of incidence and mortality worldwide for 36 cancers in 185 countries. CA: A Cancer Journal for Clinicians. 2018;68: 394-424. doi:10.3322/caac.21492

2. Torre LA, Trabert B, DeSantis CE, Miller KD, Samimi G, Runowicz CD, et al. Ovarian cancer statistics, 2018. CA: A Cancer Journal for Clinicians. 2018;68: 284-296. doi:10.3322/caac.21456

3. Bast RC. Status of Tumor Markers in Ovarian Cancer Screening. Journal of Clinical Oncology. 2003;21: 200s-2205. doi:10.1200/JC0.2003.01.068

4. Andrews L, Mutch DG. Hereditary Ovarian Cancer and Risk Reduction. Best Practice \& Research

5. Grossman DC, Curry SJ, Owens DK, Barry MJ, Davidson KW, Doubeni CA, et al. Screening for ovarian cancer US preventive services task force recommendation statement. JAMA - Journal of the American Medical Association. 2018. doi:10.1001/jama.2017.21926

6. Trimbos JB. Surgical treatment of early-stage ovarian cancer. Best Practice and Research: Clinical Obstetrics and Gynaecology. 2017. doi:10.1016/j.bpobgyn.2016.10.001

7. Mucci LA, Hjelmborg JB, Harris JR, Czene K, Havelick DJ, Scheike T, et al. Familial Risk and Heritability of Cancer Among Twins in Nordic Countries. JAMA. 2016;315: 68-76. doi:10.1001/jama.2015.17703

8. Janssens ACJW, Aulchenko YS, Elefante S, Borsboom GJJM, Steyerberg EW, van Duijn CM. Predictive testing for complex diseases using multiple genes: Fact or fiction? Genetics in Medicine. 2006;8: 395-400. doi:10.1097/01.gim.0000229689.18263.f4

9. Janssens ACJW, van Duijn CM. Genome-based prediction of common diseases: advances and

10. Torkamani A, Wineinger NE, Topol EJ. The personal and clinical utility of polygenic risk scores.

11. Lambert SA, Abraham G, Inouye M. Towards clinical utility of polygenic risk scores. Human

12. Khera A v., Chaffin M, Aragam KG, Haas ME, Roselli C, Choi SH, et al. Genome-wide polygenic

13. Pharoah PDP, Tsai Y-Y, Ramus SJ, Phelan CM, Goode EL, Lawrenson K, et al. GWAS meta-analysis

14. Kuchenbaecker KB, Ramus SJ, Tyrer J, Lee A, Shen HC, Beesley J, et al. Identification of six new scores for common diseases identify individuals with risk equivalent to monogenic mutations. Nature Genetics. 2018;50: 1219-1224. doi:10.1038/s41588-018-0183-z and replication identifies three new susceptibility loci for ovarian cancer. Nature Genetics. 2013;45: 362-370. doi:10.1038/ng.2564 doi:10.1038/ng.3185 
medRxiv preprint doi: https://doi.org/10.1101/2020.07.18.20156976; this version posted July 21, 2020. The copyright holder for this preprint (which was not certified by peer review) is the author/funder, who has granted medRxiv a license to display the preprint in perpetuity. It is made available under a CC-BY-NC-ND 4.0 International license .

15. Lewis $\mathrm{CM}$, Vassos E. Polygenic risk scores: from research tools to clinical instruments. Genome Medicine. 2020;12: 44. doi:10.1186/s13073-020-00742-5

16. Goode EL, Chenevix-Trench G, Song H, Ramus SJ, Notaridou M, Lawrenson K, et al. A genomewide association study identifies susceptibility loci for ovarian cancer at $2 q 31$ and $8 \mathrm{q} 24$. Nature Genetics. 2010. doi:10.1038/ng.668

17. Weinstein JN, Collisson EA, Mills GB, Shaw KRM, Ozenberger BA, Ellrott K, et al. The Cancer Genome Atlas Pan-Cancer analysis project. Nature Genetics. 2013;45: 1113-1120. doi:10.1038/ng.2764

18. Bell D, Berchuck A, Birrer M, Chien J, Cramer DW, Dao F, et al. Integrated genomic analyses of ovarian carcinoma. Nature. 2011;474: 609-615. doi:10.1038/nature10166

19. Hutter C, Zenklusen JC. The Cancer Genome Atlas: Creating Lasting Value beyond Its Data. Cell. 2018;173: 283-285. doi:10.1016/j.cell.2018.03.042

20. Copy Number Variation Analysis Pipeline. [cited 18 Jan 2018]. Available: https://docs.gdc.cancer.gov/Data/Bioinformatics_Pipelines/CNV_Pipeline/

21. Korn JM, Kuruvilla FG, McCarroll SA, Wysoker A, Nemesh J, Cawley S, et al. Integrated genotype calling and association analysis of SNPs, common copy number polymorphisms and rare CNVs. Nature Genetics. 2008;40: 1253-1260. doi:10.1038/ng.237

22. Olshen $A B$, Venkatraman ES, Lucito R, Wigler M. Circular binary segmentation for the analysis of array-based DNA copy number data. Biostatistics. 2004;5: 557-572. doi:10.1093/biostatistics/kxh008

23. National Cancer Institute Genomic Data Commons. [cited 18 Jan 2018]. Available: https://gdc.cancer.gov/

24. Reynolds SM, Miller M, Lee P, Leinonen K, Paquette SM, Rodebaugh Z, et al. The ISB Cancer Genomics Cloud: A Flexible Cloud-Based Platform for Cancer Genomics Research. Cancer Research. 2017;77: e7-e10. doi:10.1158/0008-5472.CAN-17-0617

25. Gijsbers P, LeDell E, Thomas J, Poirier S, Bischl B, Vanschoren J. An Open Source AutoML Benchmark. 6th ICML Workshop on Automated Machine Learning. 2019. Available: https://arxiv.org/pdf/1907.00909.pdf

26. Friedman JH. Stochastic gradient boosting. Computational Statistics and Data Analysis. 2002;38: 367-378. doi:10.1016/S0167-9473(01)00065-2

27. Tenny S, Hoffman MR. Odds Ratio (OR). StatPearls. StatPearls Publishing; 2020. Available: http://www.ncbi.nlm.nih.gov/pubmed/28613750

28. Zhang B. Colorectal cancer predictive test using germ-line DNA data and multiple machine learning methods. 2019. Available: https://escholarship.org/uc/item/44f3f487

29. Olson RS, Cava W la, Mustahsan Z, Varik A, Moore JH. Data-driven advice for applying machine learning to bioinformatics problems. Pacific Symposium on Biocomputing Pacific Symposium on Biocomputing. 2018;23: 192-203. Available: http://www.ncbi.nlm.nih.gov/pubmed/29218881 
medRxiv preprint doi: https://doi.org/10.1101/2020.07.18.20156976; this version posted July 21, 2020. The copyright holder for this preprint (which was not certified by peer review) is the author/funder, who has granted medRxiv a license to display the preprint in perpetuity.

341

342 

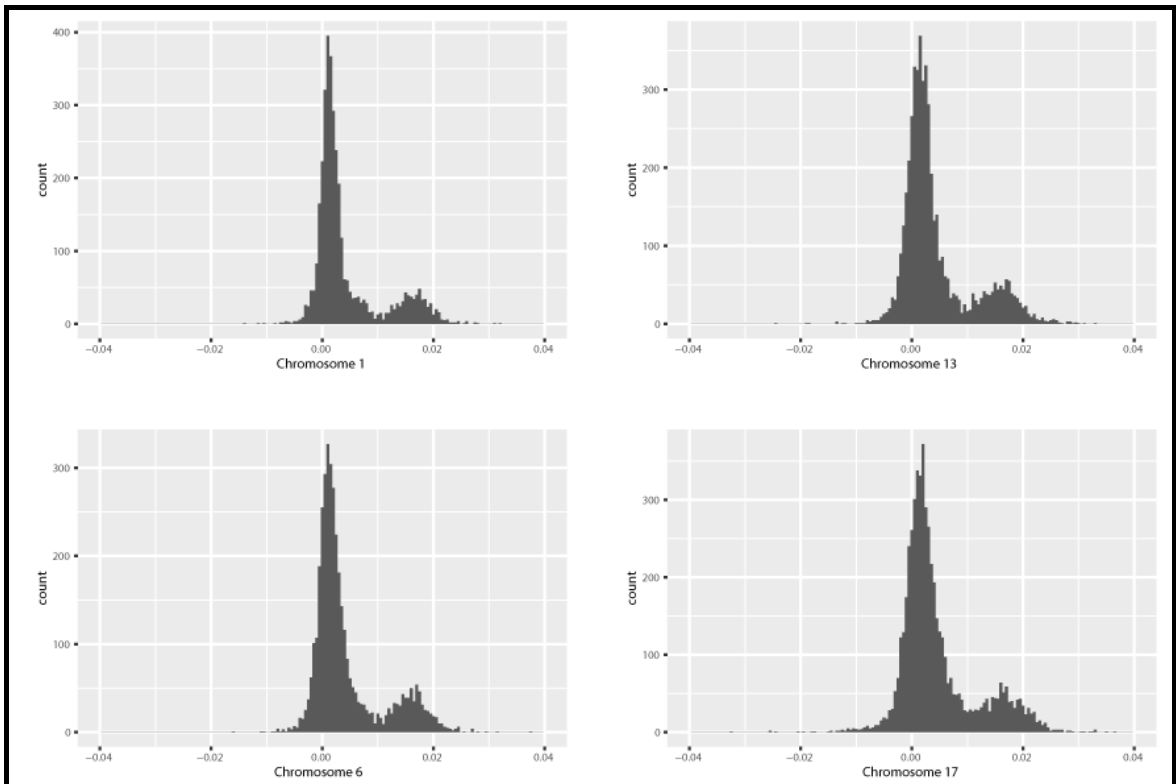

Figure 1. This shows a histogram of chromosome scale length variation for most of chromosome 17. For most patients in the TCGA dataset, a normal blood sample was taken, genomic DNA was extracted from that sample and analyzed with an Affymetrix SNP 6.0 array. The data from this array was processed by the TCGA project through a bioinformatic pipeline that resulted in a segment mean value, which is a number equal to the log base two of one half the copy number value. This histogram indicates that most people have a nominal value of 0 , indicating exactly two copies of the diploid chromosome. A value of 0.02 indicates the person has on average 2.028 copies of the chromosome, or about $1.4 \%$ longer than the average length of the chromosome. 
medRxiv preprint doi: https://doi.org/10.1101/2020.07.18.20156976; this version posted July 21, 2020. The copyright holder for this preprint (which was not certified by peer review) is the author/funder, who has granted medRxiv a license to display the preprint in perpetuity.

It is made available under a CC-BY-NC-ND 4.0 International license .

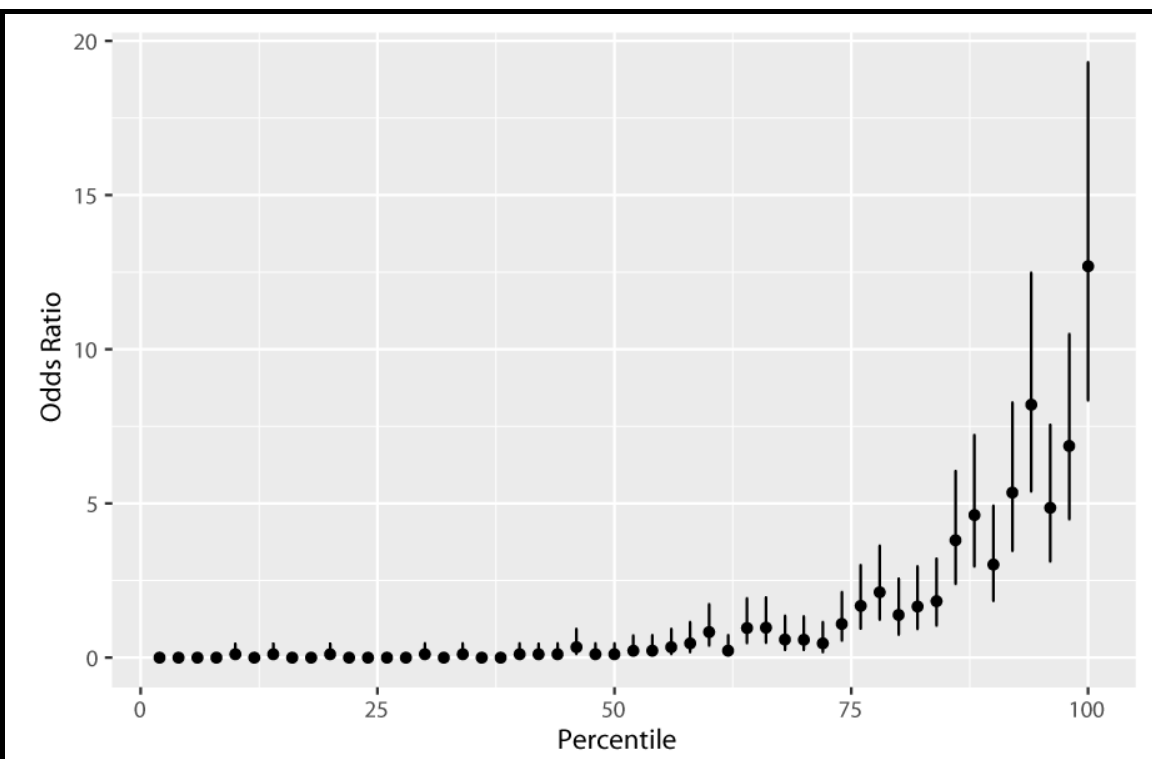

Figure 2. This figure shows that women ranked higher by the predictive model have significantly more likely to have ovarian cancer. The predictive model ranked all 4669 women in the dataset based on their likelihood of having ovarian cancer, based solely on germ line DNA data. This ranking was then split into 50 equal partitions, each with about 93 women. This plot shows the odds ratio (relative to 414 ovarian cases out of 4669 total) of each of the 50 equal partitions along with the $95 \%$ confidence intervals. 
medRxiv preprint doi: https://doi.org/10.1101/2020.07.18.20156976; this version posted July 21, 2020. The copyright holder for this preprint (which was not certified by peer review) is the author/funder, who has granted medRxiv a license to display the preprint in perpetuity.

It is made available under a CC-BY-NC-ND 4.0 International license .

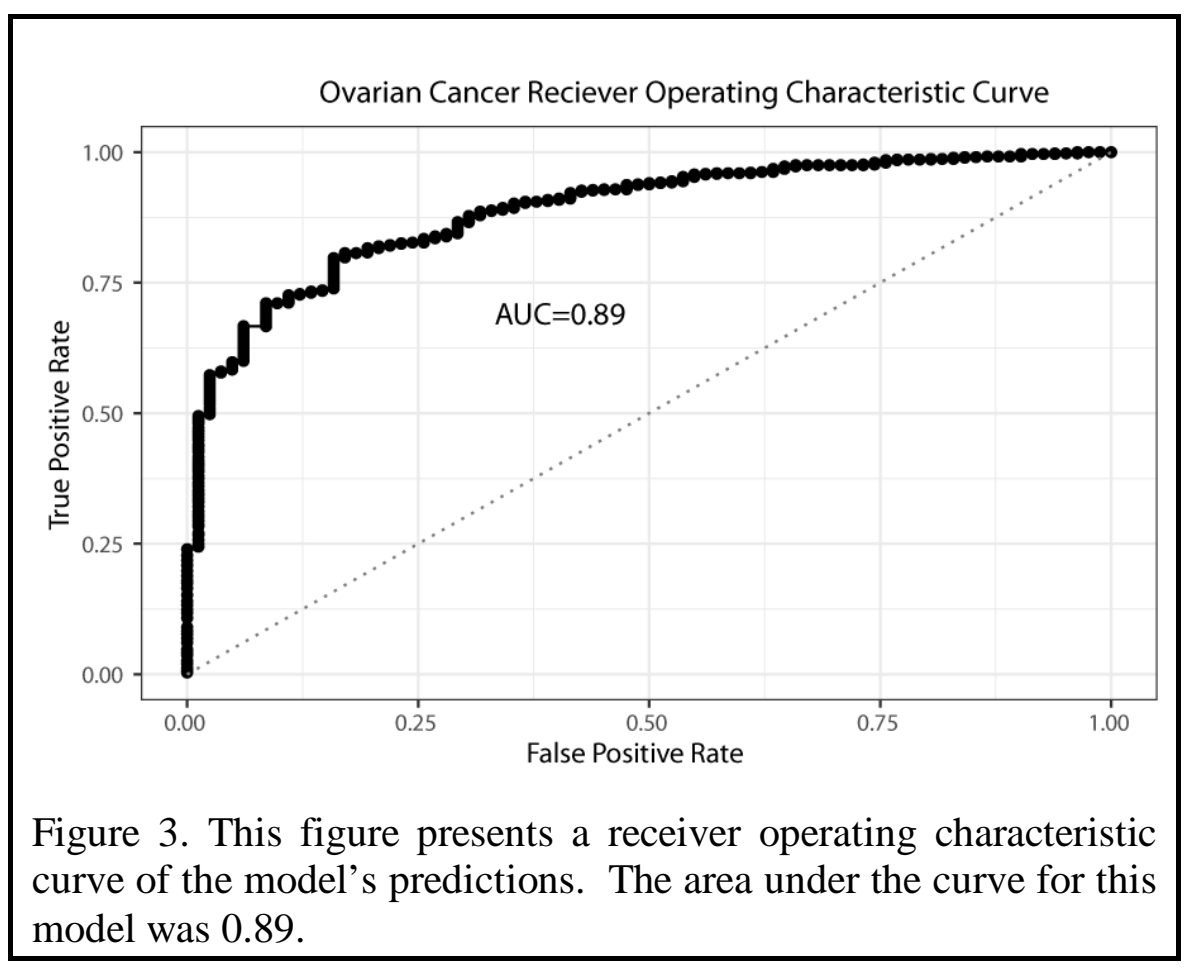

371 